\title{
Human Resources Competency in the Era of Industrial Revolution 4.0
}

\author{
Damayanti $^{1}$ \\ ${ }^{1}$ STIE YPPI Rembang
}

\begin{abstract}
An era of technological disruption is marked by digitization in various lives. Apart from offering benefits, the industrial revolution 4.0 also has challenges that must be faced. The challenges faced by a country when implementing the 4.0 industrial revolution are the emergence of resistance to changes in demographics and social aspects, instability in political conditions, limited resources, risk of natural disasters and demands for the application of environmentally friendly technology. The PESTEL framework is the basis for considering political, economic, social, technical, environmental and legal factors to analyze challenges in the era of the industrial revolution 4.0. Indonesia needs to improve the quality of workforce skills with digital technology. The relevance of education and work needs to be adjusted to the development of the era and science and technology while still paying attention to aspects of humanities. It is important to identify in competency classification, including: 1) Technical competence consists of all knowledge and skills related to work, 2) Methodological competencies include all skills and abilities for general problem solving and decision making, 3) Social competence includes all skills and abilities as well as attitudes to cooperate and communicate with others, and 4) Personal competence includes social values, motivation, and individual attitudes. New literacy, leadership, team work, mental maturity and character, culture and entrepreneurship make HR function properly in the community. The development of thematic studies in various disciplines is linked to the real world, project-based learning, through general education (extra-curricular) programs, and internships/practical work and the important thing that can support it is foreign language skills. Thus, competent human resources (HR), critical thinking, lateral thinking and entrepreneurship can be realized.
\end{abstract}

Keywords: human resources; competence; industrial revolution 4.0; technology.

\section{INTRODUCTION}

The current condition has entered the industrial era 4.0, that is, the era of technological disruption marked by digitization in various lives. The revolution of industry consists of two words, namely revolution and industry. Revolution means very fast changes, while industry is an effort to implement the production process. Thus, the revolution of industry is a change that hapens rapidly in the implementation of the production process in which the production process initially done by humans is replaced by machines to produce the merchandises which have commercial additional values. The Industrial Revolution has changed the way humans work from manual use to automation or digitization.

The industrial revolution has developed. According to Davies (2015), the industrial revolution occurred four times in the European Parliamentary Research Service. The first revolution took place in England in 1784 where the invention of the

1Email: damayanti_rahmania @yahoo.co.id P-ISSN: 2580-6084, E-ISSN: 2580-8079 
steam engine and mechanization began to replace human jobs. The second happened at the end of the 19th century (1870), in which production machines powered by electricity were used for mass production activities. The use of computer technology for manufacturing automation starting in 1969 marked the third industrial revolution. The last, the rapid development of sensor technology, interconnection, and data analysis has led to the idea of integrating all these technologies into various industrial fields.

The era of the industrial revolution 4.0 is slightly like two sides of a blade, meaning that beside its benefits it also provides challenges. If we are not ready to face it, we will be eroded by the times. Drath and Horch (2014) argue that the challenges faced by a country when implementing the 4.0 industrial revolution are the emergence of resistance to changes in demographic and social aspects, instability in political conditions, limited resources, the risk of natural disasters and the demand for environment-based technology. One of the change's aspects is the management and organization aspects. In organizational management, there is human resource management that is experiencing a shift in competence. Answering the challenges in the era of the industrial revolution 4.0, there are many things that must be done. One of them is the role of universities in preparing and creating human resources to enter the industrial era. Based on the explanation, the challenging question is how to prepare human resource competencies in facing the era of the industrial revolution 4.0. Therefore, this paper will discuss several things should be done especially the role of universities in the process.

\section{THEORETICAL BACKGROUND}

\section{The Concept of Industrial Revolution}

The term of industrial revolution 4.0 itself was officially created in Germany, exactly when the Hannover Fair was held in 2011 (Kagermann et al., (2011) in Hecklau et al., (2016)). Germany has a great interest in this revolution because Industry 4.0 is part of its policy of development plan called the High-Tech Strategy 2020. Several other countries have also participated in realizing the concept of the industrial revolution 4.0, but they use different terms such as Smart Factories, Industrial Internet of Things, Smart Industry, or Advanced Manufacturing. Merkel (2014) argues that the industrial revolution 4.0 is a comprehensive transformation of all aspects of production in industry 
through the combination of digital technology and the internet with conventional industries.

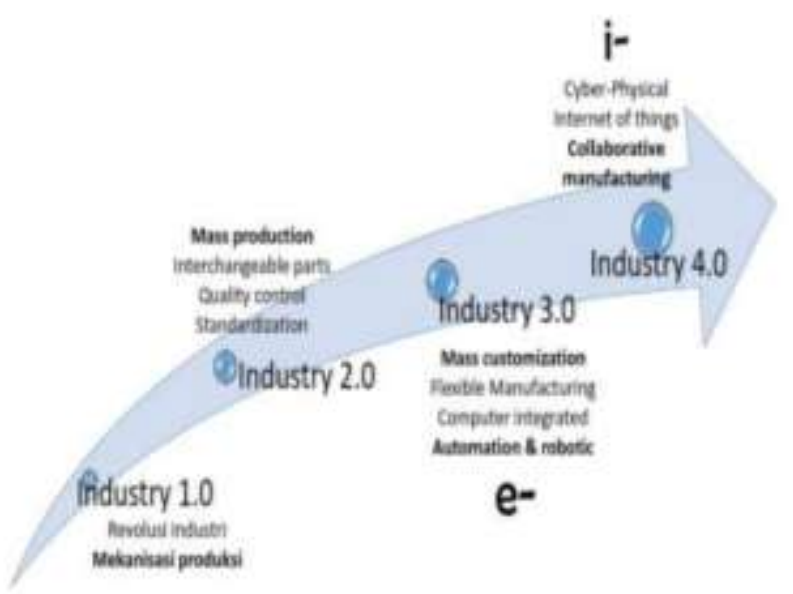

Source: Hecklau et al., (2016)

Figure 1. Industrial Revolution

Another definition conveyed by Kagermann et al., (2013) is that the industrial revolution 4.0 is the integration of the Cyber Physical System (CPS) and the Internet of Things and Services (IoT and IoS) into industrial processes including manufacturing and logistics and other processes. In brief, industrial revolution 4.0 is an industrial era in which all entities in it can communicate with each other in real time at any time based on the use of internet technology and CPS to achieve the goal of either obtaining new value creation or optimizing of existing values from each process in the industry (Prasetyo and Sutopo, 2018).

Kagermann et al., (2013), in the final report, states that the Industry 4.0 working group sponsored by the ministry of education and research in Germany has provided recommendations for the Industry 4.0 framework model. The recommended model is an embodiment of three-aspect integration. The first aspect is horizontal integration, which means integrating CPS technology into the company's business strategy and cooperation network including partners, providers, customers and other parties. The second, vertical integration concerns how to apply CPS technology to the existing manufacturing/production system in the company so that it can be flexible and modular. The third one includes the application of CPS technology into value engineering chain by end to end. The value engineering chain involves the process of adding value from the product starting from the design process, production planning, manufacturing to 
service to product customers. The integration of these aspects requires eight actions. These actions are (1) standardization, (2) modeling of complex systems, (3) provision of communication network infrastructure, (4) safety and security assurance, (5) organizational and working design, (6) human resource training, (7) legal framework certainty, and (8) resource efficiency.

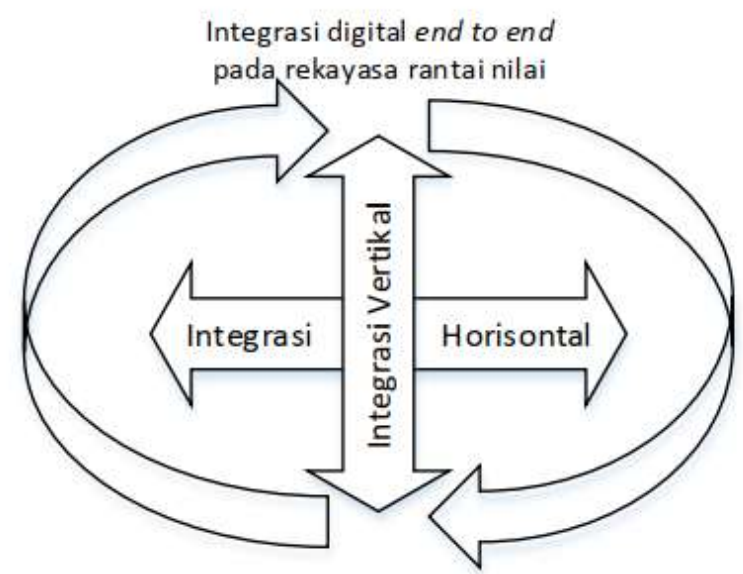

Source: Kagermann et al., (2013)

Figure 2. Three aspects of the Integration of Industri 4.0

A research and technology organization in Europe recommends other model called Fraunhofer Industrie 4.0 layer model (Neugebauer et al., 2016). This model is believed to be more comprehensive as it includes more tangible elements. This model is compiled from the results of document extraction from various studies and the results of interviews with experts. As shown in figure 3, this model is composed of three main layers. The core layer is related to production. This layer is divided into ten core technology parts, namely:

1. engineering

2. manufacturing technologies and organization

3. machines

4. smart capabilities

5. robotics and human-robot collaboration

6. production planning control

7. logistics

8. work organization 
9. workplace design and assistance

10. resource and energy efficiency.

The next layer is the aspect of information and communication technology that enables the realization of the concept of Industry 4.0. The outermost layer related to company transformation due to the implementation of Industry 4.0 includes business, management and human resources.

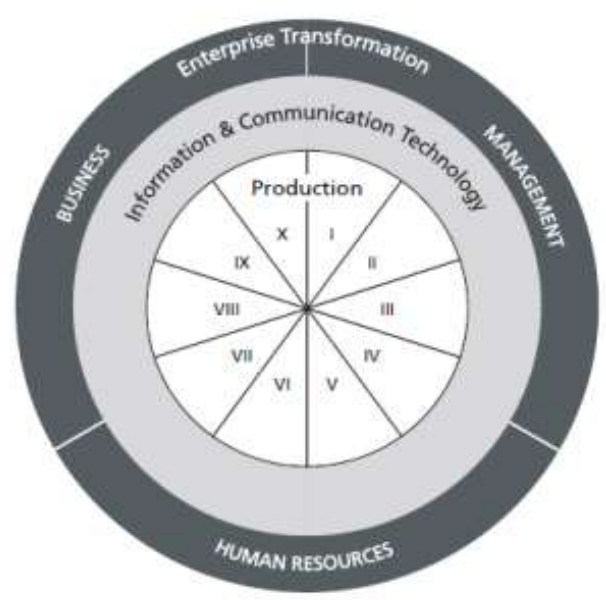

Source: Neugebauer et al., (2016)

Figure 3. The Structure of Fraunhofer Industrie 4.0 Layer Model

\section{The Aspect of Industri 4.0}

The aspect of revolution 4.0 can be seen in Table 1 .

Table 1. The Aspect of Revolution 4.0

\begin{tabular}{cll}
\hline No & \multicolumn{1}{c}{ Aspect } & \multicolumn{1}{c}{ Description } \\
\hline 1 & Standardization & $\begin{array}{l}\text { Covering all efforts to make standards and references in } \\
\text { implementing Industry 4.0. }\end{array}$ \\
2 & Modeling & $\begin{array}{l}\text { Including all efforts to model the complex system in } \\
\text { industry } \\
\text { Availability of hardware or software technology for fast } \\
\text { and real time exchange of information and data. }\end{array}$ \\
$\begin{array}{l}\text { Everything related to the security of data processing } \\
\text { network }\end{array}$ & $\begin{array}{l}\text { Systems and the security of using technology for humans. } \\
\text { Including efforts to transform human resources so that } \\
\text { they are ready to face changes due to Industry 4.0. }\end{array}$ \\
5 & Human resource & $\begin{array}{l}\text { Covering efforts to develop a legal framework for the } \\
\text { implementation of Industry 4.0 (contracts, agreements, } \\
\text { regulations, etc.). }\end{array}$ \\
6 & Law & $\begin{array}{l}\text { Including all efforts to make resource efficiency (energy, } \\
\text { cost, etc.) due to the implementation of Industry 4.0 }\end{array}$ \\
7 & Resource Efficiency &
\end{tabular}




\begin{tabular}{|c|c|c|}
\hline & & technology. \\
\hline 8 & CPS Technology & $\begin{array}{l}\text { All efforts related to the development of CPS, IoT, } \\
\text { virtualization technology, which are the keys of Industry } \\
4.0 \text { technology. }\end{array}$ \\
\hline 9 & Smart Factory & $\begin{array}{l}\text { Including development of automated, intelligent, } \\
\text { modular and adaptive manufacturing/production } \\
\text { systems. }\end{array}$ \\
\hline 10 & Business & $\begin{array}{l}\text { Including the discovery of new business models or } \\
\text { changes in business processes due to the application of } \\
\text { Industry } 4.0 \text {. }\end{array}$ \\
\hline 11 & Work Design & $\begin{array}{l}\text { Including development and research related to work } \\
\text { system changes that will be faced by workers. }\end{array}$ \\
\hline 12 & Services & $\begin{array}{l}\text { covering all efforts in processing big data and making } \\
\text { applications for its usage. }\end{array}$ \\
\hline 13 & $\begin{array}{l}\text { Management and } \\
\text { Organisation }\end{array}$ & $\begin{array}{l}\text { Related to changes and development of management and } \\
\text { organizational models due to the application of Industry } \\
4.0 \text {. }\end{array}$ \\
\hline 14 & $\begin{array}{l}\text { End to end product } \\
\text { engineering }\end{array}$ & $\begin{array}{l}\text { Related to product or service engineering that is } \\
\text { digitalized during its life cycle (smart product). }\end{array}$ \\
\hline
\end{tabular}

Source: Prasetyo and Sutopo (2018)

\section{METHOD, DATA AND ANALYSIS}

The method used in writing this article is analytical method. In a literature review, it is descriptive analysis through various literature studies in strengthening analysis supported by various sources that have theoretical depth from experts about human resource competence in the era of the industrial revolution 4.0. Through the analysis approach, this study can be used as a basis for developing knowledge and theory about human resource competencies in relation to the era of the industrial revolution 4.0. It is hoped that this paper will be useful for developments of the themes discussed.

\section{RESULTS}

The industrial revolution 4.0 provides many benefits as well as challenges in aspects of human life. The benefits of the 4.0 industrial revolution can be seen in Table 2 .

Table 2. The Potential of Benefits of Industrial Revolution 4.0

\begin{tabular}{ll}
\hline \multicolumn{1}{c}{ Writer } & \multicolumn{1}{c}{ The Potential of Benefits } \\
\hline Lasi et al., (2014) & $\begin{array}{l}\text { Delevoping product faster, realizing individual demands (product } \\
\text { customization), flexible production and responding quickly to problems } \\
\text { and efficiency of resources. }\end{array}$ \\
\hline PEmail: damayanti_rahmania@ yahoo.co.id & 18
\end{tabular}




\begin{tabular}{ll}
$\begin{array}{l}\text { Rubamann } \text { et al., } \\
(2015)\end{array}$ & $\begin{array}{l}\text { Improving productivity, boosting income growth, increasing demand for } \\
\text { skilled labor, and raising investment. }\end{array}$ \\
$\begin{array}{l}\text { Schmidt } \text { et al., } \\
\text { Realizing mass customization of products, utilizing idle data, and }\end{array}$ & $\begin{array}{l}\text { improving production time. } \\
\text { Kagerman } \text { et al., }\end{array}$ \\
$\begin{array}{l}\text { Being able to meet individual customer needs, making engineering and } \\
\text { business processes become dynamic, taking decision more optimal, } \\
\text { creating new business models and new ways of eliciting added value. }\end{array}$ \\
$\begin{array}{l}\text { Neugebaurer } \text { et } \\
\text { al., (2016) }\end{array}$ & $\begin{array}{l}\text { Realizing an efficient, intelligent and on-demand manufacturing process } \\
\text { at a reasonable cost. }\end{array}$ \\
\hline
\end{tabular}

Source: Prasetyo and Sutopo (2018)

Besides offering many benefits, the industrial revolution 4.0 also has challenges to face. Drath and Horch (2014) argue that the challenges faced by a country when implementing Industry 4.0 are the emergence of resistance to changes in demographic and social aspects, instability in political conditions, limited resources, risk of natural disasters and demands for environment-based technology application. Hecklau et al., (2016) used the PESTEL framework by considering political, economic, social, technical, environmental and legal factors to analyze challenges in the era of the industrial revolution 4.0. It is described as follows:

1. Economic challenges: the continuing process of globalization enables companies to overcome reduced time to the market, shorter product life cycles, and the need to cut costs in order to remain competitive (Spath et al., 2013). Markets are becoming increasingly volatile and heterogeneous (Spath et al., 2013).

2. Social challenges: one of the most influential social challenges is demographic change. Fewer young people enter the labor market to replace the retired (Stock, 2013).

3. Technical challenges: as a result of the exponential growth of technology, companies must be able to efficiently handle the large amounts of data (big data) (Huber and Kaiser, 2015).

4. Environmental challenges: One of the main challenges related to the environment is the ongoing climate change (Stock, 2013).

5. Political and legal challenges. The most obvious political challenge is the increasing need for research program funding (Brithl et al., 2015).

Responding to the challenges in the era of the industrial revolution 4.0, there are many things to do. Indonesian Government through the Ministry of Industry has 
developed an initiative of "Making Indonesia 4.0" to implement the 4IR strategy and Roadmap in Indonesia. This roadmap involves various stakeholders, from governmental institutions, industry associations, business actors, technology providers, to research and educational institutions. The Roadmap of Making Indonesia 4.0 provides a clear direction and strategy for the future movement of Indonesian industry, including the five sectors becoming the focus and 10 national priorities in an effort to strengthen Indonesia's industrial structure. Through the commitment and active participation of various stakeholders, including ministries and other governmental agencies, partnerships with private parties and industry players, investors, educational institutions for research institutions, Making Indonesia 4.0 is expected to be successfully carried out.

Following up Indonesian Government's policies about Making Indonesia 4.0, the Ministry of Research and Technology through the Director of Learning and Student Affairs has socialized and formulated the learning process in the era of the industrial revolution 4.0 since the beginning of 2018. One of them is that Indonesia needs to improve the quality of workforce skills with digital technology (Parray, ILO, 2017). Responding to the challenges of this era, the relevance of education and work needs to be adjusted to the development of the era and science and technology while still paying attention to aspects of humanities. Based on existing data, $8.8 \%$ of 618 thousand unemployed undergraduates (BPS, August 2017) and Indonesia's competitiveness ranked 36 out of 137 countries in the world (WEF, 2017).

In order that higher education graduates can be competitive, the curriculum needs a new orientation. In the era of the Industrial Revolution 4.0, it is inadeqate to propose old literacy (reading, writing, and mathematics) as basic assets to take part in society. Ministry of research, technology and higher education adopts a learning policy in Higher Education to prepare more competitive graduates through as the followings:

1. Data Literacy. Ability to read, analyze and use information (Big Data) in the digital world.

2. Technology Literacy. Understand the work of machines and technology applications (Coding, Artificial Intelligence and Engineering Principles).

3. Human Literacy. Humanities, communication and design.

Based on this policy, universities should develop the quality of graduates so that

1Email: damayanti_rahmania@yahoo.co.id 
they become human resources (HR) who are ready to work and can face challenges in the era of revolution 4.0. For this reason, the writer tries to develop an idea about competence based on previous research. The development of workforce to meet current and future market's needs is identified based on the required competencies. Competence is defined as a set of skills, abilities, knowledge, attitudes and motivations that individuals need to deal effectively with work-related tasks and challenges (Hecklau et al., 2016).

\section{DISCUSSION}

From the explanation the author has previously conveyed about the challenges in the revolutionary era 4.0, including political, economic, social, technical, environmental and legal factors, it is necessary to make formulation about competencies through identification of challenges. It can be seen in Table 3.

Table 3. Formulation of Competencies through Identification of Challenges

\section{Economic - Ongoing globalization}

Challenges Intercultural skills, language skills, time flexibility, network skills, process comprehension

\section{- Increasing need for innovation}

Entrepreneurial thinking, creativity, problem solving, working under pressure, current knowledge, technical skills, research skills, process understanding

- Demand for a higher service orientation

Conflict solving, communication skills, ability to compromise, networking skills

- Growth of need for cooperative and collaborative work

Ability to compromise and cooperate, ability to work in teams, communication skills, networking skills

\section{Social - Changes in demographics and social values}

Challenges Ability to transfer knowledge, accept job-task rotations and job-related changes (tolerance of ambiguity), time and place flexibility, leadership skills

- Improving virtual work

Flexibility of time and place, technology skills, media skills, understanding IT security

- Growth of process complexity

Technical skills, process understanding, learning motivation, tolerance for ambiguity, decision making, problem solving, analytical skills

Technical - Exponential growth in technology and data usage

Challenges Technical skills, analytical skills, work efficiency with data, coding skills, 
understanding IT security, compliance

- Cultivating collaborative work on the platform

Ability to work in teams, virtual communication skills, media skills, IT security understanding, ability to be cooperative

Environment - Climate change and resource scarcity

Challenges Sustainable mindset, motivation to protect the environment, creativity to develop new sustainable solutions

Political Standardization

and legal Technical skills, coding skills, process comprehension

challenges - Data security and personal privacy

Understanding IT security, compliance

Source: Hecklau et al., (2016)

Research by Hecklau et al., (2016) identified four main categories for classifying competencies by referring to the research of Becker (2013), Solga et al., (2011), and Grabmann (2005), namely:

1. Technical competence consists of all knowledge and skills related to work.

2. Methodological competence includes all skills and abilities for general problem solving and decision making.

3. Social competence includes all skills, abilities, and attitudes to cooperate and communicate with others.

4. Personal competence consists of social values, motivation, and individual attitudes.

The explanations can be seen in Table 4 .

Table 4. The Competencies Needed by Human Resources Facing the Era of Industrial Revolution 4.0

\begin{tabular}{|c|c|c|}
\hline Category & Competencies Needed & Context \\
\hline $\begin{array}{l}\text { Technical } \\
\text { Competence }\end{array}$ & $\begin{array}{l}\text { - Latest knowledge } \\
\text { - Technical skills } \\
\text { - Process } \\
\text { Undersatnding } \\
\text { - Media Skills } \\
\text { - Coding skills } \\
\text { - Understanding IT } \\
\text { Security }\end{array}$ & $\begin{array}{l}\text { - Increasing job responsibilities, and knowledge } \\
\text { becomes increasingly important } \\
\text { - Comprehensive technical skills are required to } \\
\text { shift from operational tasks to more strategic } \\
\text { tasks } \\
\text { - Higher process complexity demands a broader } \\
\text { and deeper understanding of the process. } \\
\text { - Increasing virtual jobs that require employees to } \\
\text { be able to use smart media } \\
\text { - The growth of digital processes which creates a } \\
\text { higher coding skills' need for employees } \\
\text { - Virtual work on servers or platform requires } \\
\text { employees to be aware of cyber security. }\end{array}$ \\
\hline
\end{tabular}

1Email: damayanti_rahmania@yahoo.co.id 


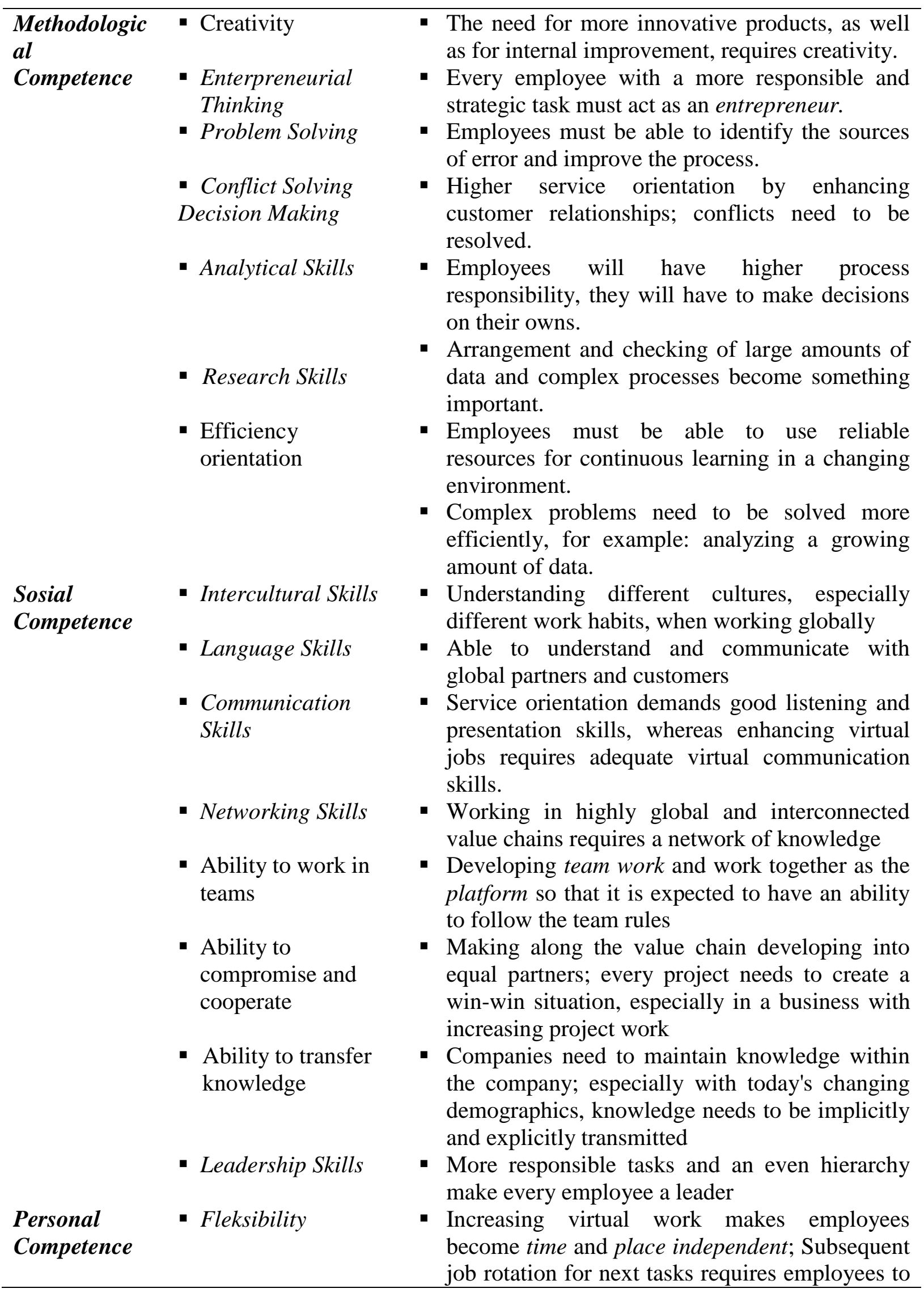

1Email: damayanti_rahmania@yahoo.co.id 
be flexible with their job responsibilities.

- Ambiguity tolerance

- Motivation to learn

- Ability to work under pressure

- Sustainable mindset

- Compliance
- Accepting changes, especially job-related changes due to rotation or work-task reorientation.

- Job-related changes require employees more frequently to be willing to learn.

- Employees involved in the innovation process need to cope with increasing pressure, due to shorter product life cycles and reduced time-tomarket.

- As representatives of their company, employees also need to support sustainability initiatives.

- Stricter rules for IT security, working machines, or working hours

Source: Hecklau et al., (2016)

Based on the description of the core competences the writer has stated, by referring to Ministry of Research, Technology and Higher Education policies, Higher Education Institutions must design an educational curriculum to adapt to the industrial era 4.0 and learning process can adopt the program based on the core competencies. From the results of a survey study of 750 employers in various industries in the US, it shows an increasing demand for job applicants to have certificates of competence, microcredentials, and professional experience besides a bachelor's degree (Callahan, 2018).

Nowadays a diploma or a certificate has not been sufficient so that university graduates as Human Resources must be ready to enter the world of work or create their own jobs (entrepreneurship). Consequently, higher education institutions should select and sort out which competencies they will develop for their graduates. In addition to the Bachelor's degree and diploma, they also need to provide a companion certificate, which includes learning outcomes, student achievements or awards, seminar participation, and other things that can improve their work eligibility. This has been done by several universities, including Technology Institute of Bandung.

Besides abilities, new literacy is needed in the digital world which can be included in elective courses, such as improving leadership skills and working in teams (team work) as well as mental maturity and character, culture and entrepreneurship in order that the graduates can implement their proper roles in the community. The development of thematic studies in various disciplines should be linked to the real 
world, project-based learning, through general education (extra-curricular) programs, and internships/practical work and foreign language skill as one of the most supporting and important factors. Therefore, it is expected that graduates are ready to become competent human resources, to think critically, laterally about many things, especially entrepreneurship.

\section{CONCLUSIONS}

The challenges faced by a country when implementing the 4.0 industrial revolution are the emergence of resistance to changes in demographics and social aspects, instability in political conditions, limited resources, risk of natural disasters and demands for the application of environment-based technology. One of the changes is a shif of human resources' competencies. For that reason, It is necessary to consider political, economic, social, technical, environmental and legal factors to analyze the challenges in the era of the industrial revolution 4.0. To follow up on Indonesian Government policies about Making Indonesia 4.0., Indonesia needs to improve the quality of workforce skills with digital technology. Answering the challenges of this era, the relevance of education and work needs to be adjusted to the development of the era and science and technology while still paying attention to aspects of humanities.

In order that higher education graduates become competitive, the curriculum needs a new orientation. In the era of the Industrial Revolution 4.0, there is not only enough to implement old literacy (reading, writing, and mathematics), but there is a need for a curriculum consisting of data literacy, technological literacy and human literacy. Workforce development to meet current and future market necessity is identified based on the required competencies. The competencies include technical, methodological, social and personal competences. Higher Education Institutions must design an educational curriculum to adapt to the industrial era 4.0., and learning process can adopt the strategy based on core competencies. New literacy is needed as well as abilities in the digital world which can be included in elective courses to improve leadership skills and working in teams (team work) as well as mental maturity and character, culture and entrepreneurship so that the graduates as Human Resources can play their roles properly in the community.

1Email: damayanti_rahmania@yahoo.co.id 


\section{REFERENCES}

Ahmad, I. (2018). Proses Pembelajaran Digital dalam Era Revolusi Industri 4.0. Direktur Jenderal Pembelajaran dan Kemahasiswaan. Kementrian Riset Teknologi dan Pendidikan Tinggi. Medan, 17 Januari 2018.

BKSTI ub.ac.id /wp-content/upload/2017/10/keynote Speker Drajad Irianto.pdf

Callahan, M. (2018). https://news.northeastern.edu/2018/12/13/heres-why-certificatesand-microcredentials-will-help-you-get-your-next-job/

Davies, R. (2015). Industry 4.0 Digitalisation for productivity and growth. http://www.europarl.europa.eu/RegData/etudes/BRIE/2015/568337/EPRS_BRI(2 015)568337_EN.pdf.

Hecklau, F., Galeitzke, M., Flachs, S., \& Kohl, H. (2016). Holistic Approach for Human Resources Management in Industry 4.0. Procedia CIRP, 54, 1-6.

Ismunandar. (2019). Peraturan-peraturan Baru yang Mendukung Prodi Inovatif. Direktur Jenderal Pembelajaran dan Kemahasiswaan. Kementrian Riset Teknologi dan Pendidikan Tinggi. Semarang, 3 Januari 2019.

Kagermann, H., Lukas, W.D., \& Wahlster, W. (2011). Industrie 4.0: Mit dem Internet der Dinge auf dem Weg zur 4. Industriellen Revolution. http://www.vdinachrichten.com/Technik-Gesellschaft/Industrie-40Internet-Dinge-Weg-4industriellen-Revolution.

Making Indonesia 4.0. (2018). Kementrian Perindustrian Republik Indonesia. http://www.kemenperin.go.id/download/18384.

Merkel, A. 2014. Speech by Federal Chancellor Angela Merkel to the OECD Conference.https://www.bundesregierung.de/Content/EN/Reden 2014/2014-0219-oecd-merkel-paris_en.html.

Pannen, P. (2018). Mempersiapkan SDM Indonesia di Era Industri 4.0. Kementrian Riset Teknologi dan Pendidikan Tinggi.

Prasetyo, H., \& Sutopo, W. (2018). Industri 4.0: Telaah Klasifikasi Aspek dan Arah Perkembangan Riset. J@ti Undip: Jurnal Teknik Industri, Vol. 13, No.1. 
Economics \& Business Solutions Journal Volume 05, Number 01, 2021, Page 13-27

Suwardana, H. (2017)s. Revolusi Industri 4.0 Berbasis Revolusi Mental. Jati Unik, Vol 1, No. 2, 102-110. 